\title{
PENGARUH CIRCUIT TRAINING DAN INTERVAL TRAINING DALAM TES KEBUGARAN JASMANI PADA EKTRAKURIKULER FUTSAL SISWA SMP
}

\author{
Arif Luqman Hakim¹, Marianus Subandowo², Ujang Rohman ${ }^{3}$ \\ 1,2,3 Program Studi Pendidikan Jasmani Pascasarjana Universitas PGRI Adi Buana Surabaya \\ Email: armand.hakim88@gmail.com¹, subanindi@gmail.com², ujang_roh64@unipasby.ac.id ${ }^{3}$
}

DOI: https://doi.org/10.36526/kejaora.v5i1.847

\begin{abstract}
ABSTRAK
Tujuan mata pelajaran penjaskes untuk meningkatkan kebugaran jasmani disemua jenis dan jenjang pendidikan. Untuk mengetahui kemampuan kebugaran jasmani seseorang dapat dilakukan melalui tes lapangan (field test) yang menuntut unjuk kerja (performance) maksimal peserta tes. Hasil tes akan menunjukkan prediksi yang akurat jika peserta tes benar-benar menampilkan kemampuan semaksimal mungkin sesuai dengan instrument yang ada. Tujuan penelitian ini adalah Untuk mengetahui manakah yang lebih berpengaruh terhadap tes kebugaran jasmani pada hasil posttest dari Circuit Training atau Interval Training, Teknik pengumpulan data yang digunakan dalam penelitian ini adalah dengan teknik tes dan pengukuran. Yaitu dengan menggunakan analisis kualitatif dan analisis kuantitatif. Analisis kualitatif dipergunakan untuk penjelasan, menggambarkan dan menafsirkan hasil penelitian dengan menggunakan susunan kata dan kalimat.Sementara analisis kuantitatif menggunakan uji t,rata-rata dan standar eror mean. Berdasarkan hasil analisisi uji t independent sampel t test dari Posttest Circuit Training dan Interval Training telah diperoleh Std. Error Mean kelompok 1 (Circuit Training) nilai 0.367 lebih besar dari Std. Error Mean kelompok 2 (Interval Training) nilai 0.327. Dengan demikian kita dapat menyimpulkan bahwa hipotesisnya berbunyi "Circuit Training lebih berpengaruh dibandingkan interval Training terhadap tes kebugaran jasmani dari hasil posttest Pada Ekstrakurikuler Futsal Siswa Smp Negeri 53 Surabaya".
\end{abstract}

Kata Kunci : Circuit Training, Interval Training, Tes Kebugaran Jasmani Indonesia

\section{PENDAHULUAN}

Setiap orang pasti menginginkan tubuhnya sehat dan bugar, sebagaimana diungkapkan oleh Mubarok ( 2015). Pada dasarnya merupakan kebutuhan setiap manusia di dalam kehidupannya agar kondisi fisik dan kesehatannya tetap terjaga dengan baik. Untuk itu, deperlukan suatu kegiatan olahraga dengan rutin dan teratur. Menurut Nurhasan (2011) latihan olahraga dapat meningkatkan kesegaran jasmani, bila memenuhi syarat-syarat sebagai berikut:

1. Intensitas latihan, yaitu beratnya kegiatanfisik dan merupakan faktor utama yang mempengaruhi kemampuan faal tubuh,

2. Frekuensi latihan, yaitu jumlah kegiatan fisik yang dilakukan dalam jangka waktu satu minggu, dan

3. Lama latihan, yaitu waktu yang digunakan dalam melakukan latihan fisik.
Salah satu cara mengukur kebugaran jasmani adalah dengan melakukan tes kebugaran jasmani, seperti pernyataan Yane (2017) secara pasti tingkat kebugaran jasmani hanya dapat diketahui melalui tes dan pengukuran. yang dilakukan oleh setiap orang. Bentuk tes dan pengukuran kesegaran jasmani bermacam-macam.

Tes merupakan alat atau prosedur yang digunakan untuk mengetahui atau mengukur sesuatu dalam suasana, dengan cara dan aturan-aturan yang sudah ditentukan.( Arikunto, 2010). Ditambahkan pula oleh Abidin (2018), tes dapat didefinisikan sebagai suatu pernyataan atau tugas atau seperangkat tugas yang direncanakan untuk memperoleh informasi tentang trait (sifat) atau atribut pendidikan atau psikologik yang setiap butir pertanyaan atau tugas tersebut mempunyai jawaban atau ketentuan yang dianggap benar. 
Jurnal Kejaora: Jurnal Kesehatan Jasmani dan Olah Raga

ISSN: 2541-5042 (Online)

ISSN: 2503-2976 (Print)

Volume 5 Nomor 1, Edisi April 2020

Untuk mengetahui kemampuan kebugaran jasmani, menurut Palar (2015) kebugaran secara umum dapat diartikan sebagai kemampuan fisik seorang dalam melakukan kegiatan atau kerja secara efisien tanpa timbul kelelahan yang berarti, seseorang dapat dilakukan melalui tes lapangan. (field test) yang menuntut unjuk kerja (performance) maksimal peserta tes. Hasil tes akan menunjukkan prediksi yang akurat jika peserta tes benar-benar menampilkan kemampuan semaksimal mungkin sesuai dengan instrument yang ada. Hal ini didukung oleh pernyataan Khaerudin (2015) kualitas suatu tes hasil belajar sangat ditentukan oleh kualitas item-itemnya. Tes hasil belajar yang berisi item-item yang berkualitas tinggi walaupun dalam jumlah yang sedikit akan jauhlebih berguna dari pada tes hasil belajar yang berisi puluhan item berkualitas rendah.

Field test yang menuntut unjuk kerja (performance) maksimal peserta tes. Hasil tes akan menunjukkan prediksi yang akurat jika peserta tes benar-benar menampilkan kemampuan semaksimal mungkin sesuai dengan instrument yang ada. Hal ini didukung oleh pernyataan Khaerudin (2015) kualitas suatu tes hasil belajar sangat ditentukan oleh kualitas item-itemnya. Tes hasil belajar yang berisi item-item yang berkualitas tinggi walaupun dalam jumlah yang sedikit akan jauhlebih berguna dari pada tes hasil belajar yang berisi puluhan item berkualitas rendah.

Beberapa jenis pilihan tes kebugaran jasmani yang dianggap paling baik dan fleksibel untuk dilaksanakan. Tes Kebugaran Jasmani Indonesia (TKJI) adalah suatu tolak ukur untuk mengukur tingkat kesegaran jasmani yang berbentuk rangkaian tes yang dibagi sesuai usia yang di tes atau diukur. Sebagaimana diungkapkan oleh Putra (2019),tes ini bertujuan untuk menentukan indeks kesanggupan badan untuk melakukan kerja, di sini kita menilai kebugaran dan kemampuan untuk pulih dari kerja berat. Tes Kebugaran Jasmani Indonesia yang disebut juga TKJI ini dibagi menjadi 4 golongan instrument tes sesuai dengan usia yaitu : 1) Usia 6 s/d 9 tahun; 2) Usia $10 \mathrm{~s} / \mathrm{d} 12$ tahun; 3) Usia 13 s/d 15 tahun; 4) Usia 16 s/d 19 tahun 
Jurnal Kejaora: Jurnal Kesehatan Jasmani dan Olah Raga

ISSN: 2541-5042 (Online)

ISSN: 2503-2976 (Print)

Volume 5 Nomor 1, Edisi April 2020

Bandura (Yuzarion, 2017) Faktor-faktor yang mempengaruhi prestasi belajar dibangun dari dua faktor utama,yaitu: (1) faktor perilaku (faktor internal) peserta didik; dan (2) faktor lingkungan (faktor eksternal) peserta didik dalam belajar.

Dalam teknik dasar minimal pemain menguasai teknik dasar yang biasa dimainkan di lapangan sepak bola. Tohari (2017) dalam permainan sepak bola dibutuhkan teknik ketrampilan dasar yang kuat. Adapun teknik tersebut yaitu : 1) menggiring bola, 2) mengumpan bola, 3) menahan bola, 4) menedang bola.

Tujuan kegiatan ekstrakurikuler yang dilaksanakan di SMP Negeri 53 khususnya ekstrakurikuler adalah untuk mengisi waktu luang dan menyalurkan minat bakat serta meningkatkan prestasi siswa tersebut. Melalui kegiatan tersebut dapat memanfaatkan waktu luangnya dengan kegiatan-kegiatan yang positif. Sehingga diharapkan siswa terhindar dari pengaruh kegiatan negatif seperti, kebiasaan merokok, minum-minuman air keras, main game, nongkrong, dan lain-lain.

Dengan mengikuti ekstrakurikuler olahraga, siswa dapat meningkatkan kebugaran jasmaninya yang dirasa kurang jika hanya melakukan aktivitas olahraga pada jam pelajaran penjaskes yang hanya 3 jam pelajaran setiap minggu. (Mahanta, 2018). Faktor lain yang menyebabkan kesegaran jasmani rendah adalah waktu yang tersedia dalam pelajaran Penjasorkes, hal ini didukung oleh pernyataan Sugiarto (2015), ialah terbatasnya waktu untuk pendidikan jasmani.

Setiap pemain dituntut untuk mempunyai skill, menurut Rohmah (2017) dalam pengertian skill yaitu sebagai kelebihan yang dimiliki oleh seorang pegawai dalam melaksanakan suatu rangkaian tugas yang berkembang dari hasil penelitian dan pengalaman saat bekerja,yang mumpuni supaya bisa membuat tim menjadi solid. Latihan ekstrakurikuler futsal membutuhkan kondisi fisik yang stabil karena sangat mempengaruhi teknik, taktik pemain. Sebagaimana pendapat Supriyanto (2016), dengan demikian, seorang pemain sepakbola yang tidak menguasai keterampilan teknik

dasar bermain tidaklah mungkin akan menjadi pemain yang baik

Untuk cabang olahraga sepakbola komponen kondisi fisik yang dibutuhkan adalah daya tahan, fleksibilitas, kelincahan, daya ledak, kecepatan dan lain-lain. Seperti yang dijelaskan Sulasmono (2016) kondisi fisik sangat menentukan kualitas dan kemampuan pemain karena dengan kondisi fisik yang baik maka seorang pemain mampu berkonsentrasi penuh dalam permainan. Derajat kebugaran jasmani seseorang sangat menentukan kemampuan fisiknya dalam melaksanakan tugas sehari-hari. Dengan kata lain, hasil kerjanya kian produktif jika kebugaran jasmaninya kian meningkat. Menurut Arifin (2018) Dalam dunia pendidikan kebugaran jasmani peserta didik merupakan aspek penting yang dapat meningkatkan mobilitas dalam meraih prestasi akademik secara maksimal.

Sehubungan dengan hal tersebut siswa hendaknya selalu menjaga dan meningkatkan kebugaran jasmani, Kebugaran jasmani adalah kemampuan seseorang dalam menjalankan jenis kegiatan fisik yang memerlukan kekuatan, daya tahan, dan fleksibilitas (Pratiwi dalam Supriyoko, 2018) siswa hendaknya selalu menjaga dan meningkatkan kebugaran jasmaninya agar dapat melakukan kegiatan sehari-hari dengan produktif terlebih untuk mengikuti latihan dengan baik. Siswa yang memiliki kebugaran jasmani yang baik akan memiliki kondisi fisik yang baik. Dengan memiliki kondisi fisik yang baik siswa, menurut Toruan (2013), kondisi fisik merupakan aspek penting dalam olahraga prestasi karena kondisi fisik merupakan aspek yang langsung berdampak terhadap performa atlit, pastinya segar dan bugar, dalam kondisi tersebut siswa akan memiliki tingkatan konsentrasi, daya tahan, kekuatan, kelentukan, kecepatan reaksi-aksi serta koordinasi yang baik. Sehingga siswa dapat menguasai teknik dasar dan dapat memahami taktik dalam bertanding sehingga nantinya akan berpengaruh terhadap kualitas untuk meraih prestasi yang maksimal.

Sirkuit training menurut Erawati (2016) Circuit training atau latihan sirkuit adalah latihan yang dilakukan dengan membentuk beberapa pos latihan. Gabungan beberapa 
Jurnal Kejaora: Jurnal Kesehatan Jasmani dan Olah Raga

ISSN: 2541-5042 (Online)

ISSN: 2503-2976 (Print)

Volume 5 Nomor 1, Edisi April 2020

pos inilah yang diibaratkan sebagai sebuah sirkuit. Setiap pos memiliki satu bentuk latihan dengan fungsi dan tujuan tertentu, ditambahkan pula oleh Suharjana (2013), latihan sirkuit adalah suatu bentuk atau model atau metode dalam suatu program latihan terdiri dari beberapa stasiun atau pos dan di setiap stasiun seorang atlet melakukan jenis latihan yang telah ditentukan: merupakan salah satu metode latihan fisik yang pelaksanaannya berdasarkan pos/stasiun yang telah disusun sebelumnnya.Pendapat tersebut menjelaskan bahwa latihan sirkuit mampu meningkatkan berbagai komponen kondisi fisik termasuk kecepatan dan daya tahan.

Pendapat di atas menjelaskan bahwa latihan sirkuit terdiri dari beberapa pos/stasiun yang berbeda bentuk latihannya di setiap pos. Satu sirkuit latihan dinyatakan selesai apabila seseorang telah melakukan latihan di seluruh pos yang telah disusun sebelumnya sesuai dengan waktu yang telah ditentukan. Menurut Rezot (2016), latihan Sirkuit atau Circuit Training merupakan latihan yang mampu memperbaiki keseluruhan fitness tubuh secara bersamaan, baik daya tahan tubuh, komponen power, fleksibilitas, maupun komponen-komponen lainnya Bentuk latihan sirkuit harus disusun sedemikian rupa sesuai kebutuhan. Menurut Syathir (2019) dalam latihan sirkuit dapat berbentuk kombinasi dari seluruh usnur fisik. Latihan tersebut bisa berupa lari naik turun tangga, lari ke samping, ke belakang, melempar bola, memukul bola dengan raket, melompat, berbagai bentuk latihan beban dan sebagainya. Bentuk latihannya bisa disusun dalam lingkaran, sehingga nama latihan ini disebut latihan sirkuit. Bentuk latihan circuit training dengan 5 pos, antara lain sebagai berikut: 1) Pos 1 sit up sebanyak 60 detik , 2) Pos 2 push up sebanyak 60 detik, 3) Pos 3 back up sebanyak 60 detik, 4) Pos 4 squat jump sebanyak 60 detik, 5) Pos 5 lari sprint dengan jarak 20 detik.

\section{年

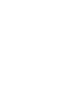

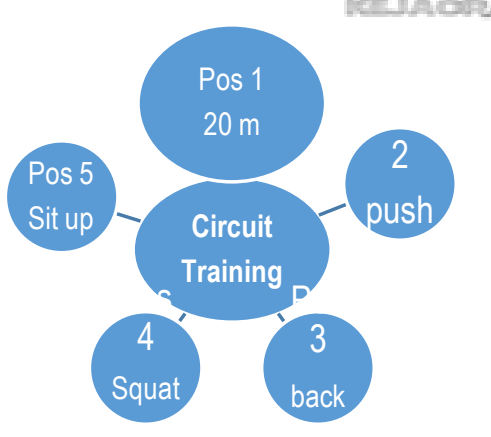

Gambar 1.Bentuk Latihan Sirkuit

Penetapan tujuan latihan; sebagaimana pernyataan Langga (2016) latihan adalah proses melakukan kegiatan yang telah direncanakan secara sistematis dan terstruktur dalam jangka waktu yang lama untuk meningkatkan kemampuan gerak baik dari segi fisik, teknik, taktik, dan mental untuk menunjang ke-berhasilan siswa atau atlet dalam memperoleh prestasi olahraga yang maksimal; merupakan faktor penting yang harus diperhatikan dalam penyusunan bentuk latihan di setiap pos.Pendapat tersebut menjelaskan bentuk latihan sirkuit yang digunakan pada metode ini adalah shuttle run, push-up, lari menyilang, Squat trust jump, lari langkah kecil, shit-up, lari zigzag dan loncat katak.

Latihan Interval adalah suatu sistem latihan yang diselingi dengan interval-interval yang berupa masa-masa istirahat (Harsono dalam Sungkowo, 2015). Latihan interval mempunyai dampak yang positif bagi perkembangan daya tahan maupun stamina tubuh. Menurut Jonath (Hardiansyah, 2017) Interval training berdasarkan prinsip interval, yaitu latihan menurut interval training ditandai oleh variasi lama pembebanan (panjang jarak/besar seri latihan), variasi intensitas beban (kecepatan/beban berlebih), variasi interval beban (lama istirahat), dan bentuk istirahat terhadap pembebanan komponenkomponen beban.

Interval training lambat akan tetapi dengan jarak lebih jauh: Lama latihan : 60 detik-3 menit, Intensitas latihan : $60 \%-75 \%$ max, Ulangan lari : 10 - 20 kali, Istirahat : 3-5 menit. 
Jurnal Kejaora: Jurnal Kesehatan Jasmani dan Olah Raga

ISSN: 2541-5042 (Online)

ISSN: 2503-2976 (Print)

Volume 5 Nomor 1, Edisi April 2020

Tabel 1. Interval Training Lambat Dengan Jarak Lebih Jauh

\begin{tabular}{llll}
\hline Repetisi & $\begin{array}{l}\text { Jarak } \\
\text { (meter) }\end{array}$ & $\begin{array}{l}\text { Waktu } \\
\text { (detik) }\end{array}$ & $\begin{array}{l}\text { Istirahat } \\
\text { (menit) }\end{array}$ \\
\hline $\mathbf{3}$ & 800 & 160 & 5 \\
\hline $\mathbf{3}$ & 600 & 120 & 4 \\
\hline $\mathbf{5}$ & 400 & 80 & 3 \\
\hline $\mathbf{5}$ & 300 & 60 & 2 \\
\hline
\end{tabular}

Waktu terbaik $800 \mathrm{~m}: 2$ menit 20

Melihat fenomena diatas penulis tertarik untuk meneliti dan membahas dalam penulisan tesis dengan judul : Pengaruh Circuit Training Dan Interval Training Dalam Tes Kebugaran Jasmani Pada Ekstrakurikuler Futsal Siswa Smp Negeri 53 Surabaya.

\section{METODE}

Penelitian pendekatan kuantitatif, penelitian perbandingan adalah suatu penelitian yang membandingkan satu kelompok sampel lainnya berdasarkan variabel atau ukuran-ukuran tertentu (Maksum, 2012).

Desain yang peneliti gunakan ialah pretest-posttest group design, karena sebelum diberikan perlakuan (treatmen) sampel terlebih dahulu akan diberikan tes awal (pre-test). Untuk mengetahui meningkatnya daya tahan tubuh, kekuatan, reaksi dan kecepatan dengan menggunakan tes akhir (post-test). Sebagaimana pernyataan Purwanto (Damayanti, 2017), pre-test diberikan sebelum penyuluhan dan bertujuan untuk mengetahui sejauh mana pengetahuan responden tentang materi yang akan diberikan, fungsi pre-test untuk melihat efektifitas penyuluhan. Sementara posttest diberikan setelah pemberian materi penyuluhan dengan tujuan untuk mengetahui sampai dimana pemahaman responden terhadap materi penyuluhan setelah kegiatan dilaksanakan Pre-test diberikan sebelum penyuluhan dan bertujuan untuk mengetahui sejauh mana pengetahuan responden tentang materi yang akan diberikan, Fungsi pre-test untuk melihat efektifitas penyuluhan. Sementara posttest diberikan setelah pemberian materi

penyuluhan dengan tujuan untuk mengetahui sampai dimana pemahaman responden terhadap materi penyuluhan setelah kegiatan dilaksanakan.

Desain yang peneliti gunakan ialah pretest-posttest group design, karena sebelum diberikan perlakuan (treatmen) sampel terlebih dahulu akan diberikan tes awal (pre-test). Untuk mengetahui meningkatnya daya tahan tubuh, kekuatan, reaksi dan kecepatan dengan menggunakan tes akhir (post-test). Sebagaimana pernyataan Purwanto (Ndaru Andri Damayanti,2017:145) Pre-test diberikan sebelum penyuluhan dan bertujuan untuk mengetahui sejauh mana pengetahuan responden tentang materi yang akan diberikan, Fungsi pre-test untuk melihat efektifitas penyuluhan. Sementara posttest diberikan setelah pemberian materi penyuluhan dengan tujuan untuk mengetahui sampai dimana pemahaman responden terhadap materi penyuluhan setelah kegiatan dilaksanakan Pre-test diberikan sebelum penyuluhan dan bertujuan untuk mengetahui sejauh mana pengetahuan responden tentang materi yang akan diberikan, Fungsi pre-test untuk melihat efektifitas penyuluhan. Sementara posttest diberikan setelah pemberian materi penyuluhan dengan tujuan untuk mengetahui sampai dimana pemahaman responden terhadap materi penyuluhan setelah kegiatan dilaksanakan.

Tabel 2. Interval Training Cepat Dengan Jarak Lebih

\begin{tabular}{cccc}
\multicolumn{4}{c}{ Dekat } \\
\hline Repetisi & $\begin{array}{c}\text { Jarak } \\
\text { (meter) }\end{array}$ & $\begin{array}{c}\text { Waktu } \\
\text { (detik) }\end{array}$ & $\begin{array}{c}\text { Istirahat } \\
\text { (menit) }\end{array}$ \\
\hline 5 & 50 & 8 & 30 \\
\hline
\end{tabular}

Penelitian ini merupakan penelitian pre test - post test design. Desain ini terdapat pre test sebelum diberi perlakuan dengan demikian hasil perlakuan dapat diketahui lebih akurat, karena dapat dibandingkan dengan hasil sebelum diberikan perlakuan. Desain Penelitian ini dapat digambarkan sebagai berikut : 


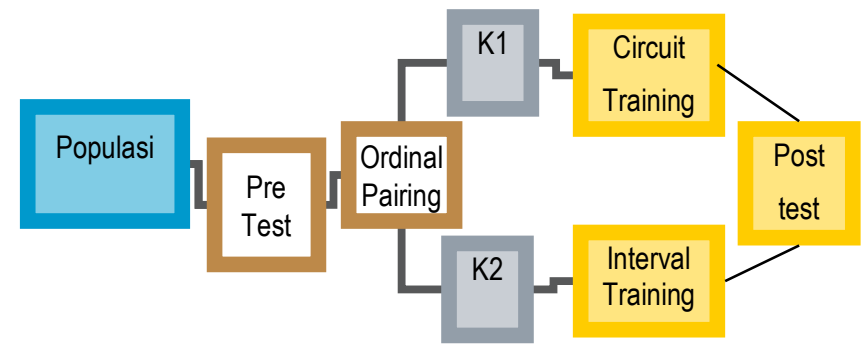

Gambar 2.Alur Penelitian

Pembagian kelompok eksperimen yang mengunakan latihan circuit training dan interval training didasarkan pada hasil melakukan tes awal kebigaran jasmani lalu dirangking mulai dari tingkat tertinggi sampai tingkat terendah, kemudian subjek yang memiliki setara dipasangkan kedalam kelompok 1 dan 2, dikelompokkan ganjil genap yang dinamakan ordinal pairing.

1. Bentuk latihan circuit training dengan 5 pos, antara lain sebagai berikut :

a. Pos 1 sit up sebanyak 60 detik

b. Pos 2 push up sebanyak 60 detik

c. Pos 3 back up sebanyak 60 detik

d. Pos 4 squat jump sebanyak 60 detik

e. Pos 5 lari sprint dengan jarak 20 meter

2. Interval Training Cepat Dengan Jarak Lebih Dekat, Waktu terbaik 100 m : 14 detik.

Prosedur atau langkah kerja pada Penelitian ini adalah one group pretest posttest design, pelaksanaan penelitian meliputi :

1. Tes awal atau pre test

Tes awal bertujuan untuk memperoleh data awal tingkat kemampuan sampel sebelum diberikan treatment atau perlakuan. Tes awal dilakukan dilapangan SMP Negeri 53 Surabaya. Tes yang dilakukan dalam penelitian ini yaitu tes TKJI pada usia 13-15 tahun. Sebelum melakukan tes, sampel dianjurkan untuk melakukan pemanasan, setelah itu sampel melakukan serangkaian tes TKJI yang terdiri dari 5 item sebanyak 1 kali. Cara pengukuran tes TKJI ini yaitu mengikuti peraturan yang ada pada tes TKJI.
2. Treatment atau perlakuan

Pemberian Treatment atau perlakuan selama 16 kali pertemuan, merupakan batas minimal dalam melakukan Treatment atau perlakuan tersebut. Sampel dibagi menjadi 2 kelompok yang mana kelompok 1 dengan eksperimen circuit training dan kelompok 2 dengan eksperimen interval training. Pembagian ordinal pairing yaitu dari rangkin nilai tingkat tinggi sampai ke yang paling rendah. Latihan mulai pukul 16.00 sampai selesai dan dlaksanakan dalam 1 minggu 2 kali pertemuan. Kegiatan latihan interval dan sirkuit terhadap kebugaran jasmani ini dilakukan dengan tiga tahap yaitu :

a. Warming Up (pemanasan)

Siswa diwajibkan melakukan pemanasan supaya mengurangi resiko cidera dan menyiapkan fisik stabil dalam melakukan tes, pemanasan dilakukan kurang lebih 15 menit dengan diawali pelemasan otot (statis), persendian dan gerakangerakan yang menunjang latihan (dinamis).

b. Latihan Inti (Treatment atau perlakuan)

Latihan dilakukan selama 40 menit pada setiap pertemuan, yang dimana sudah dibagi menjadi 2 kelompok eksperimen dan melakukan program yang sudah tersusun.

c. Pendinginan

Setelah melakukan aktivitas atau latihan, sampel perlu melakukan pendinginan dengan tujuan otot kembali normal seperti keadaan semula. 
Jurnal Kejaora: Jurnal Kesehatan Jasmani dan Olah Raga

ISSN: 2541-5042 (Online)

ISSN: 2503-2976 (Print)

Volume 5 Nomor 1, Edisi April 2020

3. Tes Akhir atau Post Test

Tes akhir dilakukan setelah sampel melakukan Treatment atau perlakuan selama 16 kali pertemuan. Tes akhir ini dilakukan seperti tes awal yaitu tes TKJI. Tujuan dari tes akhir ini adalah untuk mengetahui hasil dari setelah Treatment atau perlakuan. Tes akhir ini, pertama diawali dengan sampel diberikan penjelasan tentang melakukan tata cara tes kebugaran jasmani, sebelum melakukan tes, sampel disarankan untuk pemanasan terlebih dahulu, kemudian menunggu giliran untuk melakukan tes dengan waktu yang disesuaikan dengan item tes. Hasil tes akhir dicatat kemudian diolah dengan statistik untuk mengetahui berpengaruh atau tidak circuit training dan interval training dalam tes kebugaran jasmani Pada Ekstrakurikuler Futsal Siswa Smp Negeri 53 Surabaya.

\section{HASIL DAN PEMBAHASAN}

Penelitian ini bermaksud untuk mengetahui apakah ada pengaruh sebelum dan sesudah melakukan latihan dengan dibagi menjadi dua kelompok dengan program latihan yang dipilih yaitu Circuit Training Dan Interval Training serta Perbedaan Pengaruh Circuit Training Dan Interval Training Dalam Tes Kebugaran Jasmani Pada Ekstrakurikuler Futsal Siswa Smp Negeri 53 Surabaya. Hasil penelitian diperoleh berdasarkan pada hasil pretest dan postest data Kebugaran Jasmani Peserta Ekstrakulikuler Futsal Siswa Smp Negeri 53 Surabaya.

1. Kebugaran Jasmani Peserta Ekstrakulikuler Futsal Siswa Smp Negeri 53 Surabaya dengan Circuit Training.

a. Data Pretest

Hasil dari tes Kebugaran Jasmani Peserta Ekstrakulikuler Futsal Siswa Smp Negeri 53 Surabaya dengan Circuit Training pretest dan Posttest.

b. Hasil dari tes Kebugaran Jasmani Peserta Ekstrakulikuler Futsal Siswa Smp Negeri 53 Surabaya dengan Interval Training dan Posttest

Berdasarkan hasil penelitian pada tabel $\mathrm{di}$ atas diperoleh persentase peningkatan pada hasil kebugaran jasmani peserta ekstrakulikuler Futsal Siswa Smp Negeri 53 Surabaya rata-rata dari hasil pretest adalah 16,1 untuk kelompok circuit training krateria sedang, rata-rata dari hasil pretest adalah 16,2 untuk kelompok interval training dengan krateria sedang, sedangkan rata-rata dari hasil posttest adalah 22,3 untuk kelompok circuit training krateria baik sekali, rata-rata dari hasil posttest adalah 21,8 untuk kelompok interval training dengan krateria krateria baik. Dengan demikian maka dengan program circuit training lebih berpengaruh dari interval training.

Analisis data digunakan untuk menjawab hipotesis yang telah diajukan pada bab sebelumnya. Uji analisis yang digunakan adalah uji normalitas, uji homogenitas dan uji hipotesis (uji t). Hasil uji normalitas, uji homogenitas dan uji $t$ dapat dilihat sebagai berikut:

1. Uji Normalitas

Perhitungan normalitas bertujuan untuk mengetahui apakah sampel berasal dari populasi yang berdistribusi normal.

a. Pre dan Post Circuit Training Berdasarkan hasil output diatas diketahui nilai signifikansi pada uji kolmogorov-smirnov pada variabel pretest dan posttest lebih dari ( > 0.05), sehingga berdasarkan uji normalitas kolomogorov -smirnov data berdistribusi normal.

b. Pre dan Post Interval Training

Berdasarkan hasil output diatas diketahui nilai signifikansi pada uji kolmogorov-smirnov pada variabel pretest dan posttest lebih dari ( > 0.05), sehingga berdasarkan uji normalitas kolomogorov-smirnov data berdistribusi normal.

\section{Uji Homogenitas}

Uji homogenitas berguna untuk menguji kesamaan sampel yaitu seragam atau tidak varian sampel yang diambil dari populasi.

a. Prestest Circuit Training dan Interval Training 
Jurnal Kejaora: Jurnal Kesehatan Jasmani dan Olah Raga

ISSN: 2541-5042 (Online)

ISSN: 2503-2976 (Print)

Volume 5 Nomor 1, Edisi April 2020

Berdasarkan hasil output Prestest Circuit Training dan Interval Training diketahui nilai signifikansi $(0.905>$ 0.05) sehingga dapat disimpulkan bahwa varians bersifat homogen.

b. Posttest Circuit Training dan Interval Training

Berdasarkan hasil output Posttest Circuit Training dan Interval Training diketahui nilai signifikansi $(0.631>$ 0.05) sehingga dapat disimpulkan bahwa varians bersifat homogen.

3. Ujit

Uji t dalam penelitian ini dimaksudkan untuk menjawab hipotesis yang telah diajukan. Pengujian hipotesis dilakukan untuk mengetahui penerimaan atau penolakan hipotesis yang diajukan, uji hipotesis menggunakan uji-t (paired sample t test) dan (independent sample $t$ test) pada taraf signifikan $95 \%$.

a. Pre dan Post Circuit Training

Berdasarkan hasil analisisi uji t paired sampel $t$ test, Pre dan Post Circuit Training telah diperoleh nilai sig. (2tailed) sebesar $0,000<$ dari 0,05 , hasil tersebut menunjukkan bahwa nilai sig. (2-tailed) sebesar 0,000 lebih kecil dari 0,05 . Dengan demikian kita dapat menyimpulkan bahwa hipotesisnya berbunyi "ada pengaruh yang signifikan Circuit Training dalam tes kebugaran jasmani Pada Ekstrakurikuler Futsal Siswa Smp Negeri 53 Surabaya".

b. Pre dan Post Interval Training

Berdasarkan hasil analisisi uji t paired sampel $t$ test Pre dan Post Interval Training telah diperoleh nilai sig. (2tailed) sebesar $0,000<$ dari 0,05 , hasil tersebut menunjukkan bahwa nilai sig. (2-tailed) sebesar 0,000 lebih kecil dari 0,05 . Dengan demikian kita dapat menyimpulkan bahwa hipotesisnya berbunyi "ada pengaruh yang signifikan Interval Training dalam tes kebugaran jasmani Pada

Ekstrakurikuler Futsal Siswa Smp Negeri 53 Surabaya". c. Posttest antara Circuit Training dan Interval Training

Berdasarkan hasil analisisi uji $t$ independent sampel $t$ test dari Posttest Circuit Training dan Interval Training telah diperoleh Std. Error Mean kelompok 1 (Circuit Training) nilai 0.367 lebih besar dari Std. Error Mean kelompok 2 (Interval Training) nilai 0.327 .

Dengan demikian kita dapat menyimpulkan bahwa hipotesisnya berbunyi "Circuit Training lebih berpengaruhdibandingkan interval Training terhadap tes kebugaran jasmani dari hasil posttest Pada Ekstrakurikuler Futsal Siswa Smp Negeri 53 Surabaya."

\section{KESIMPULAN}

1. Penerapan Pretest Dan Posttes Circuit Training berpengaruh terhadap peningkatan tes kebugaran jasmani Pada Ekstrakurikuler Futsal Siswa Smp Negeri 53 Surabaya.

2. Penerapan Pretest Dan Posttes Interval Training berpengaruh terhadap peningkatan tes kebugaran jasmani Pada Ekstrakurikuler Futsal Siswa Smp Negeri 53 Surabaya.

3. Penerapan Circuit Training lebih berpengaruh daripada Interval Training terhadap peningkatan tes kebugaran jasmani Circuit Training Dan Interval Training Pada Ekstrakurikuler Futsal Siswa Smp Negeri 53 Surabaya.

\section{SARAN}

Berdasarkan hasil analisis dan hasil penelitian yang telah dilakukan, peneliti dapat memberikan saran kepada guru olahraga I Pembina ekstrakurikuler Futsal yang akan mengikuti kegiatan perlombaan dengan menyiapkan atlitnya dengan memiliki fisik yang baik pada usia 13-15 tahun / SMP, untuk hasil yang lebih maksimal dengan cara memberikan pelatihan secara fisik maupun teknik, melalui latihan Circuit Training.

\section{DAFTAR PUSTAKA}

\begin{tabular}{ccc} 
Abidin, $Z$. (2018). & \multicolumn{2}{c}{ Pengertian } \\
Tes, Pengukuran, & Penilaian & Dan \\
Evaluasi Serta Etika Tes,
\end{tabular} 
Jurnal Kejaora: Jurnal Kesehatan Jasmani dan Olah Raga

ISSN: 2541-5042 (Online)

ISSN: 2503-2976 (Print)

Volume 5 Nomor 1, Edisi April 2020

https://ikumpul.blogspot.com/2018/12/ pengertian-tes-pengukuran-penilaiandan-evaluasi.html,Diakses 18/3/2020

Arifin, Z. (2018). Pengaruh Latihan Senam Kebugaran Jasmani (Skj) Terhadap Tingkat Kebugaran Siswa Kelas V Di Min Donomulyo Kabupaten Malang, http://e-journal.staimaalhikam.ac.id/index.php/al-mudarris/ Vol. 1 No. 1 / April 2018, p ISSN: 26205831 | e ISSN: 2620 - 435 5, Diakses $22 / 3 / 2020$

Arikunto, S. (2010). Dasar-Dasar Evaluasi Pendidikan (Edisi Revisi). Jakarta: Bumi Aksara.

Damayanti, N. A., Pusparini, M., Djannatun, T., \& Ferlianti, R. (2017) Metode PreTest Dan Post-Test Sebagai Salah Satu Alat Ukur Keberhasilan Kegiatan Penyuluhan Kesehatan Tentang Tuberkulosis Di Kelurahan Utan Panjang,

JakartaPusathttp://proceeding.unisba. ac.id/index.php/kesehatan/article/view /1131/pdf,Diakses 25/3/2020

Hardiansyah, S. (2017) Pengaruh Metode Interval Training Terhadap Peningkatan Kesegaran Jasmani Mahasiswa Jurusan Pendidikan OlahragaVol.4No.1,https://Ejournal.U ndiksha.Ac.Id/Index.Php/Penjakora/Ar ticle/View/13369/8401,Diakses25/3/2 020

Irawati, D. (2016) Circuit Training, Latihan Yang Fun Dan Menantang https://www. planetsports.asia/blog/po st/circuit-training-latihan-yang-fundan-menantang,Diakses 3/3/2020

Khaerudin. (2015) Kualitas Instrumen Tes Hasil Belajar, Jurnal Madaniyah, Volume 2 Edisi IX Agustus 2015,Diakses 18/3/2020

Langga, Z., \& Anfidi, S. (2016) Pengaruh Model Latihan Menggunakan Metode Praktik Distribusi Terhadap Keterampilan Dribble Anggota Ekstrakurikuler Bolabasket Smpn18Malang,Vol.1No.1Http://Journ al.Um.Ac.Id/Index.Php/Jko/Article/Do wnload/7711/3529,Diakses 24/3/2020

Lestari, R.Y. (2016) Peran Kegiatan Ekstrakurikuler Dalam

Mengembangkan Watak Kewarganegaraan peserta Didik, Untirta Civic Education Journal ( UCEJ ), Vol. 1, No. 2, Desember 2016, Hal. 136-152, Diakses 20/3/2020

M, Syathir. (2019). Latihan Sirkuit ( Circuit Training ) 1 , https://www.bacaki.id/2019/latihansirkuit-circuit-traing.html, Diakses 24/3/2020

Mahanta, A.A.F., \& Nurhayati, F. (2018) Hubungan Antara Status Gizi Dengan Tingkat Kebugaran Jasmani Siswa Kelas

AtasDiSditUtsmanBinAffanSurabaya, http://ejournal.unesa.ac.id/index.php/j urnal-pndidikan-

jasmani/issue/archive/Diakses $21 / 3 / 2020$

Maksum, A. (2012). Metodologi Penelitian. Surabaya: UNESA University Press.

Mubarok, H., Rahayu, S., \& Hidayah, T. (2015). Analisis Profil Tingkat Kesegaran Jasmani Pemain Futsal Anker Fc Tahun 2014, http://journal.unnes.ac.id/sju/index.ph p/jssf,Diakses 17/3/2020.

Nurhasan. (2011). Tips Praktis Menjaga Kebugaran Jasmani. Gresik: Abil Pustaka

Palar, C.M., Wongkar, D., \& Ticoalu, S.H.R. (2015). Manfaat Latihan Olahraga Aerobik Terhadap Kebugaran Fisik Manusia, Jurnal e-Biomedik (eBm), Volume 3, Nomor 1, Januari-April 2015,Diakses 18/3/2020

Permana, R. (2016). Penguasaan Rangkaian Tes Kebugaran Jasmani Indonesia(Tkji) Melalui Diskusi Dan Simulasi, Jurnal Refleksi EdukatikaVol. 6 No. 2 Juni 2016, Diakses 19/3/2020

Rezot, K. (2016). Pengertian Latihan Sirkuit Pada Kebugaran Jasmani, https://materiku86.blogspot.com/2016 /10/Latihan-sirkuit html, Dikases 23/3/2020

Rohmah, A.N. (2017). Strategi Pengembangan Skill Pegawai Dalam Meningkatkan kualitas Pelayanan Di Kspps Bmt Al-Hikmah Ungaran Cabang Mijen 
Jurnal Kejaora: Jurnal Kesehatan Jasmani dan Olah Raga

ISSN: 2541-5042 (Online)

ISSN: 2503-2976 (Print)

Volume 5 Nomor 1, Edisi April 2020

Http://Eprints.Walisongo.Ac.Id/7246/3

/Bab\%20ii.Pdf ,Diakses 22/3/2020

Saputra, S., \& Sugiyanto, D. (2019). Studi Kebugaran Jasmani Menggunakan Metode Harvard Step Tes Pada Mahasiswa Penjas Semester Vi Universitas Bengkulu Tahun Akademik 2018-2019, Jurnal IImiah Pendidikan Jasmani, 3 (2) 2019,Diakses 19/3/2020

Sugiarto, B.G. (2015). Pengaruh Distribusi Alokasi Waktu Pembelajaran Pendidikan Jasmani Terhadap Perilaku Hidup Aktif Dan Kebugaran Jasmani Siswa SekolahDasar, http://jurnal.unismabekasi.ac.id/index. php/motion/article/download/528/418/ Di akses 21/3/2020

Suharjana. (2013). Kebugaran Jasmani. Yogyakarta: Jogja Global Media.

Sukadiyanto. (2011). Pengantar Teori Dan Metodologi Melatih Fisik.Bandung; CV Lubuk Agung.

Sulasmono, R. (2016). Analisis Deskriptif Kondisi Fisik Pemain Sepak bola ssb Tunas Jaya Sidoarjo,http://jurnalmahasiswa.unes a.ac.id/index.php/jurnal-kesehatan olahraga /article/download/17780/16194,Diaks es $22 / 3 / 2020$

Sungkowo, R., Kaswarganti, B., \& Kumbu, S. (2015). Pengaruh Latihan Interval dan Kapasitas Vital Paru terhadap Kecepatan Renang 50 Meter Gaya Crawl,http://journal.unnes.ac.id/nju/in dex.php/miki, Volume 5. Nomor 1. Edisi Juli 2015. ISSN: 2088-6802, Diakses 2/3/2020

Supriyanto, E. (2016). Pengaruh Pendekatan Teknis Dan Taktis Terhadap Keterampilan Teknik Dasar Permainan Sepakbola Pada Siswa Smpn1Kotabumi,http://Digilib.Unila.A c.Id/25431/3/Tesis\%20tanpa\%20bab \%20pembahasan.Pdf, Diakses $22 / 3 / 2020$

Tohari, M.A. (2017). Vol.2 No.1, Analisis Teknik Ketrampilan Dasar Permainan Sepakbola Pada Akademi Kresnabina Pesepakbola Surabaya Pada Pemain 